\title{
Universiteit
}

Leiden

The Netherlands

\section{Missionaries, Hereros, and motorcars: mobility and the impact of motor vehicles in Namibia before 1940}

Gewald, J.B.

\section{Citation}

Gewald, J. B. (2002). Missionaries, Hereros, and motorcars: mobility and the impact of motor vehicles in Namibia before 1940. International Journal Of African Historical Studies, 35(2/3), 257-285. Retrieved from https://hdl.handle.net/1887/4837

Version: $\quad$ Not Applicable (or Unknown)

License: $\quad$ Leiden University Non-exclusive license

Downloaded from: https://hdl.handle.net/1887/4837

Note: To cite this publication please use the final published version (if applicable). 
Missionaries, Hereros, and Motorcars: Mobility and the Impact of Motor Vehicles in Namibia before 1940

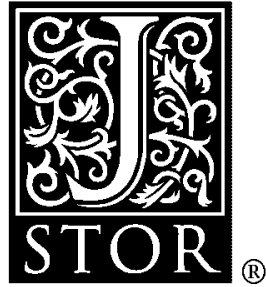

\author{
Jan-Bart Gewald
}

The International Journal of African Historical Studies, Vol. 35, No. 2/3 (2002), 257-285.

Stable URL:

http://links.jstor.org/sici?sici=0361-7882\%282002\%2935\%3A2\%2F3\%3C257\%3AMHAMMA\%3E2.0.CO\%3B2-3

The International Journal of African Historical Studies is currently published by Boston University African Studies Center.

Your use of the JSTOR archive indicates your acceptance of JSTOR's Terms and Conditions of Use, available at http://www.jstor.org/about/terms.html. JSTOR's Terms and Conditions of Use provides, in part, that unless you have obtained prior permission, you may not download an entire issue of a journal or multiple copies of articles, and you may use content in the JSTOR archive only for your personal, non-commercial use.

Please contact the publisher regarding any further use of this work. Publisher contact information may be obtained at http://www.jstor.org/journals/buafc.html.

Each copy of any part of a JSTOR transmission must contain the same copyright notice that appears on the screen or printed page of such transmission.

JSTOR is an independent not-for-profit organization dedicated to creating and preserving a digital archive of scholarly journals. For more information regarding JSTOR, please contact support @ jstor.org. 


\section{MISSIONARIES, HEREROS, AND MOTORCARS:}

\section{MOBILITY AND THE IMPACT OF MOTOR VEHICLES IN NAMIBIA BEFORE 1940*}

\section{By Jan-Bart Gewald}

In the 1930s a German missionary motoring to and from his congregants in the Khomas Hochland Mountains in central Namibia was surprised by a cloudburst. The missionary battled on, but became stuck in one of the many normally bone-dry riverbeds that criss-cross central Namibia. As the missionary struggled, the river came down in flood. The wheels were immersed and then water flooded into the car itself. Gamely the missionary sought to prevent the car from being washed away. Up to his chest in water, the missionary watched in horror as an uprooted tree swept its majestic way towards his car. The tree threatened to come to rest against the side of his car, which would have meant that further detritus would build up against the tree and his car would then be swept away. With superhuman effort, Missionary Werner wrestled with the tree. Fortunately the waters started to subside and, apart from being thoroughly soaked, Werner was able to recount the tale of his close escape. ${ }^{1}$

While Werner was struggling with the car, several strapping young Herero men were watching his activities but refused to assist him. Werner had called out to the Herero for assistance; professing adherence to the Roman Catholic faith, they had refused to help. What is important here is not so much that they had inculcated the tenets of Roman Catholicism to such an extent that they refused to assist a person of another faith, but, far more important, that they refused to help another human being. Though it is not customary to indulge in counterfactual histories, it is interesting to speculate about what might have happened had Werner been traveling in a wagon. While traveling slowly he would have been in direct contact with those he was traveling among; someone recognized and remembered is a person and not an anonymous apparition at a great remove that happens to zoom past in a motorized vehicle from time to time.

* Research for this paper was conducted under the auspices of the ACACIA SFB 389 research project of the German Research Foundation at the University of Cologne, Germany. An earlier version of this paper appeared in Jan-Bart Gewald, "We Thought We Would Be Free": Socio-Cultural Aspects of Herero History in Namibia, 1915-1940 (Cologne, 2000).

1 United Evangelical Mission Archives, Wuppertal, Germany (VEMA) RMG 1703, Werner in Windhoek, 21/12/33, to Olpp. 
While conducting research into the manner in which Herero viewed and portrayed their history in the 1920 s and 1930s, I noticed that the Rhenish Missionary sources, which had hitherto been so informative, all tended to dry up. While trying to discover why this should be so, I stumbled across the issue of the motorcar's introduction to the missionaries of the Rhenish Mission society and to Namibia as a whole. ${ }^{2}$

This article seeks to explore the social impact of the motorcar on the relationship between the colonial state, the mission, and the Herero. It looks at how perceptions of space and reality changed, how information regarding these factors and society changed, and how both Herero and European missionaries were affected by, and dealt with, the introduction of the motorcar into their midst.

\section{The Introduction of the Motorcar}

It was in 1904, the first year of the Herero-German war, that the first vehicle driven by an internal combustion engine was introduced to Namibia. ${ }^{3}$ Following the rinderpest epidemic of 1896, the limitations of transport based on ox-wagons had become clear. Indeed, the rinderpest outbreak hastened the establishment of the first of a series of railway lines in the territory. ${ }^{4}$ Though trains were not dependent on grazing, did not need to rest during the heat of the day, and could transport far more goods at greater speed than any oxwagon ever could, the train was dependent on, and bound to follow, the railway line. That is, even though goods could be transported at record speed to any point along the line, the further conveyance of these goods was still dependent on ox-wagons and other forms of animate portage. The logistics of the Herero-German war brought to the fore just how precarious German military operations based on animal transport could be..$^{5}$ It was in trying to over-

2 J. B. Gewald, "Herero and Missionaries: The Making of Historical Sources in the, 1920s," in Wilhelm J.G. Möhlig, ed., Frühe Kolonialgeschichte Namibias 1880-1930 (Cologne, 2000), 77-95.

${ }^{3}$ Namibian National Archives Windhoek (NNAW) Photo 4923, Troostsche Kraftwagen von Hpt. Eberhardt montiert, Swakopmund, 1904.

4 For a detailed overview on the development of railways in Namibia, see Gerhardus Pool, Pionierspoorweë in Duits-Suidwes-Afrika 1897-1915 (Durban, 1982), and Brenda Bravenboer and Walter K. E. Rusch, The First 100 Years of State Railways in Namibia (Windhoek, 1997).

5 German forces imported thousands of mules from Argentina, and shipped in tons of fodder from Australia. Most of the mules were soon out of action due to the climate. For a detailed description of the difficulties experienced by the German army in Namibia see: Kriegsgeschichtlichen Abteilung 1 des Großen Generalstabes, Die Kämpfe der deutschen Truppen in Südwestafrika (Berlin, 1906); Kommando der Schutztruppen im ReichsKolonialamt, Sanitäts-Bericht über die Kaiserliche Schutztruppe für Südwestafrika während des Herero- und Hottentottenaufstandes für die Zeit vom 1. Januar, 1904 bis 31. März, 1907 
come these limitations that an eccentric German officer, Lt. Troost, began experimenting with different forms of mechanized transport that could operate independently from a railway line. ${ }^{6}$ The failed results of one of his first experiments, a steam-powered locomotive on huge iron wheels, can still be found rusting 15 kilometers inland from the port city of Swakopmund, at the point where it came to rest, never to move again. The rusting hulk is referred to by Swakopmund residents as the "Martin Luther," this in reference to the cleric's famous dictum, "Here I stand; I cannot do otherwise."7 Though Troost's first attempt ended in dismal failure, his second attempt was far more successful. In 1904, various parts were shipped ashore and assembled in Swakopmund, after which a huge contraption powered by an internal combustion engine and drawing three wagons lumbered off into the Namibian interior. $^{8}$ Though self-propelled trucks and cars had but little effect on the course of events in the Herero-German war, the motorcar was to have profound effects upon the course of the First World War as it was fought in Namibia.

Almost immediately after World War I had been declared, German forces engaged with South African forces in the northern Cape. Following a series of battles in which it became increasingly clear that an overland invasion from the northern Cape would be exorbitantly costly in terms of human life, the South Africans landed an invasion force at Walvis Bay. After taking the coastal town of Swakopmund, the South Africans were able to advance directly into the heart of the territory. Unable to retain control over the capital, the Germans withdrew northwards, where their commander, Franke, hoped to make use of the well-watered terrain and close proximity to Angola to hold out against the South Africans. What he had not counted upon was that the South African forces were highly mobile, motorized to a large extent, and, more important, equipped with armored cars. ${ }^{9}$ What this meant was that while Franke deployed his forces to meet the massed ranks of infantry marching overland to confront him, he and his forces were outflanked by cavalry, armored car, and motorized infantry units. In a surprisingly short period of time, Franke, renowned for his ruthless activities in the Herero-German war

(Berlin, 1909); and Kirtsen Zirkel, "Militärische Struktur und Politische Führung im DeutschSuidwestafrika-Krieg, 1904-07" (Magister thesis, H. Heine Universität Düsseldorf, 1989).

6 Edmund Troost, "Erlebnisse einer Straßenlokmotive," in Gesellschaft für Wissenschaftliche Entwicklung Swakopmund, Nachrichten, Jahrgang 34, Heft 1/02, 33-42.

7 Bravenboer and Rusch, Railways in Namibia, 14-15. Troost later featured in a fictionalized account of the wars in Namibia: Uwe Timm, Morenga (Cologne, 1985), 274-81.

${ }^{8}$ NNAW, BSW 69, Troost'sche Kraftwagen, 1904.

${ }^{9}$ These armored cars were based on the chassis of Rolls Royce Silver Shadows. Gerald l'Ange, Urgent Imperial Service: South African Forces in German South West Africa, 1914-1915 (Cape Town, 1991), 232-40. 
and the hero of the German colonists in the territory, found himself surrounded and forced into an ignoble surrender. ${ }^{10}$

Undoubtedly emboldened by the performance of motorcars in Namibia, the South Africans deployed cars in their subsequent campaign against German forces in Tanganyika. Here, however, the dense bush, relentless rain, and difficult terrain rendered the motor vehicles less useful. In Namibia, however, the motorcar had come to play a central role in warfare and, subsequently, in the enforcement of colonial rule.

\section{The Car and Colonial Rule}

In Namibia the motorcar soon became an indispensable tool in the enforcement of colonial rule. The car and the airplane were part and parcel of the new technology of intimidation and domination, in which the colonial authority used the new technology not solely for its undoubted utilitarian values, but also for its symbolic and awe-inspiring abilities. ${ }^{11}$ Colonial authorities were impressed by the ability of their motorized vehicles and expected that their colonial subjects would be similarly impressed. That is, motorized vehicles, whether airplanes or cars, were seen by the colonists as a material manifestation of their technological superiority and hence by extension their natural moral superiority, which in turn legitimated their right to rule. ${ }^{12}$ The diaries of missionary and colonial officials are littered not just with references to the new technology, but also with photographs of that technology, illustrating their awe and respect as children of the industrial age. ${ }^{13}$ Colonial officials were themselves the products of a society soaked through with the ethic of modernization, a society in which the high priests were the technological wizards who created, worked, and shaped the industries of the world. These industries produced chemicals for pharmaceuticals, fertilizers, clothing, death, and destruction; or surgical steel, agricultural implements, looms, tanks, and bombers. Industrialization and modernization were almost wholly integrated

\footnotetext{
${ }^{10}$ L'Ange, Urgent Imperial Service, 280-329.
}

11 Erdmute Alber, "Motorisation and Colonial Rule," paper presented at the "Everyday Life in Colonial Africa" Symposium at the Institute for African Studies at the University of Leipzig, 6-7 October 1998, $1 \mathrm{fn}$. 1. The introduction of the airplane in Namibia was similar to that of the motorcar. Airplanes were used to bomb the Bondelswarts into submission, and thereafter used during the Rehoboth revolt; after that revolt, South African Air Force planes flew sorties bombing the bush around other settlements in the territory in what the missionaries referred to as a "bomb greeting."

12 Michael Adas, Machines as the Measure of Men: Science, Technology, and Ideologies of Western Dominance (Ithaca, NY, 1990), 21-68, 221-36.

13 This is particularly well illustrated in the photographs and particularly the cover of W. Hartmann, P. Hayes, and J. Silvester, The Colonising Camera: Photographs in the Making of Namibian History (Cape Town and Athens, Ohio, 1998). 
into conceptions of what was entailed by civilization, and hence justice and morality. Thoroughly convinced that their understanding of the world was the only true understanding, colonial officials acted out their roles in the belief that their access to the truth would overshadow the falsehoods of their subjects. After all, if they were awed and impressed by the beauty of their weapons, then it stood to reason that their colonial subjects would be similarly impressed. We must bear this in mind when we deal with the colonial state's deployment of motorized vehicles in situations where their strictly physical utilitarian values were not immediately obvious. The vehicles were used to impress through their mere presence and as the physical manifestation of the innate superiority of the modernized world.

The first local ruler to experience the full impact of the motorcar was the Kwanyama chief, Mandume, whose forces were literally run to ground by motorcars. ${ }^{14}$ The photographs taken during the course of this expedition are of interest precisely because they indicate how dependent, and, more particularly, how aware the South African forces were of the technological achievements of their world. Apart from a particularly tasteless image detailing the beheading of Mandume, the photographs detail the course of the expedition through the medium of motor vehicles. Smiling soldiers pose next to motor vehicles being loaded onto trains for the trip north. Panoramic shots show cars on flatbeds and troops in cattle trucks. Other images show cars struggling through the mopane forests of northern Namibia; soldiers standing on vehicles, repairing punctures, or tinkering with engines; and vehicles roaring across the open expanses of Ovamboland. ${ }^{15}$ The photographs do not follow particular individuals but are focused on the progress of the motor vehicles-the subject matter of the photographer through which the expedition against an African king is brought to expression. The motor vehicle was an essential and integral part of this expedition; it was innovative and it was what made the expedition important in terms of the self-consciousness of the colonial soldiers who took part in it. ${ }^{16}$

For all its symbolic values, the fact remains that the car was able to transfer people from one place to another faster and with greater endurance than any horse could ever hope to muster. The extended distances that colonial officials had to travel in the course of their duties in Namibia ensured that the

14 Jeremy Silvester, My Heart Tells Me That I Have Done Nothing Wrong: The Fall of Mandume (Windhoek, 1992).

15 NNAW Photographs, 14724, 6100, 6126, 6156, 6165, 6969, 6977, 6984.

16 NNAW ADM 49 Mandume Affair, OC Union Forces in Windhoek, 31/3/17, to The Administrator, SWA Protectorate. 
motorcar came to be seen as an essential part of their equipment. ${ }^{17}$ With cars colonial officials could cover journeys such as the one from Gobabis to Aminuis, which used to take 16 days, within the course of a single day. ${ }^{18} \mathrm{With}$ motorcars colonial officials could cover more households per day while collecting taxes or conducting censuses. Police in cars could patrol greater tracts of land without having to rely on water holes or riverbeds. Colonial officials, often desk-bound on account of age or health, could extend their active service in the field. In short, the introduction of the car into South African colonial service meant that the presence of colonial officials increased substantially on the ground. In addition, this presence became highly standardized. Dates of arrival and departure could be arranged with a far greater degree of certainty than in the past. Historical evidence elsewhere in southern Africa confirms this trend:

Cars in Southern Rhodesia, more generally, were important in transforming the rules regarding white supervision of mission schools. After cars came in, the rules became codified around four visits per year by the white supervisor (earlier, government officials frequently acknowledged that walking or horseback riding or bicycling to remote stations often was not feasible). ${ }^{19}$

Concomitantly, however, the introduction also ensured that large sections of social activity in the territory were now effectively screened and hidden from the view of colonial officials. Bound to roads, officials now hardly ever strayed into terrain that would previously have been traversed on foot or on horseback. Without access to a car, officials balked at having to visit certain locations. Indeed, there were times when officials faced with the absence of a motor vehicle simply refused to fulfil their duties. An added aspect of this was, simply, that colonial officials were poorly informed about events that took place in sites that were inaccessible by motor vehicle. Thus in 1923, when Captain Bowker was invited to attend the investiture of Hosea Kutako by Friedrich Maharero at the Orumbo reserve, Bowker refused to attend on the grounds that he had no car at his disposal. ${ }^{20}$

Colonial officials now motored on a regular basis to places hardly ever visited before. The advent of the motorcar also meant that certain water points,

17 See in particular the photos of Cocky Hahn, Nos. 147-52, in Hartmann, Hayes, and Silvester, The Colonising Camera.

18 NNAW, SWAA 2081 A 460/5 Gobabis, 1918-1951, Report on Working of Native Locations Gobabis.

${ }^{19}$ Carol Summers, personal communication via H-Africa@H-Net.MSU.edu, 19/2/98.

${ }^{20}$ See in this regard Bowker, who was invited to attend Friedrich Maharero's installation of Hosea Kutako as his representative in Namibia. 
trading stores, settlements, and indeed police and administrative posts lost their importance and were overshadowed by other centers. The best example of this in the Namibian context is that of Otjimbingwe. In the 1880s Otjimbingwe was one of the most important settlements in South West Africa, and thousands of people, hundreds of wagons, and tons of goods passed through this settlement. The first German colonial officials used the settlement as their base. However, rinderpest and the advent of the railway, which passed to the north of the settlement, ensured that within ten years Otjimbingwe was but a shadow of its former self. ${ }^{21}$ The advent of the motorcar ensured that from the beginning of South African occupation, all official dealings relating to Otjimbingwe were conducted through Karibib.

While some areas became inaccessible or lost their importance in the eyes of the colonial administration, others were forced to submit to colonial penetration for the first time. Motor companies like Panhard, Renault, and Fiat sponsored major "scientific" expeditions across and through Africa in the 1920 s and 1930s. It is my contention that this phenomenon should be seen as a general trend that expressed colonial domination in physical form. As a classic icon of the modern technological world, the superior presence of motor vehicles in those parts of the world considered to be primitive continues to have great appeal. ${ }^{22}$ Accounts of expeditions set up in southern Africa-to find the lost city of the Kalahari, or to traverse the Kalahari-are replete with continual comparisons between the primitive and the modern. ${ }^{23} \mathrm{~A}$ fine example of this is the Denver expedition for the lost Bushman in northern Namibia, so well documented and illustrated by Rob Gordon. ${ }^{24}$ More often than not these expeditions were presented as quests for scientific knowledge. Thus, much like the Denver expedition, the Bechuanaland administration sponsored an expedition through the Kalahari with the assistance of Morris six-wheeler trucks, ostensibly to increase the administration's knowledge of water resources in the territory. ${ }^{25}$ It is remarkable to see to what degree the participants of this particular expedition appropriated power. Thus the expedition members, imbued with

${ }^{21}$ Evangelical Lutheran Church Archives in the Republic of Namibia (ELCRN), V. 26 Ortschronik Otjimbingwe, details Otjimbingwe's decline in importance. See in particular the year 1899, in which the railway line via Karibib was opened.

22 The romanticism associated with adventure and expeditions is there for every Camel trophy rider. The popularity of films such as "The English Patient," documentaries such as "The Bush Tucker Man," and metropolitan academic programs operating in Southern Africa are also manifestations of this. See Gordon, Picturing Bushmen, 19-31, 68-70.

23 A. J. Clement, The Kalahari and Its Lost City (Johannesburg, 1967), 195-96. Lawrence Green, To the River's End (Cape Town, 195?), 28-35.

${ }^{24}$ Gordon, Picturing Bushmen, 69, Plate BA 63.

25 Botswana National Archives (BNA), Secretariat, S.2/7/1-4, Morris Six-Wheeler Lorry Kalahari Expedition. 
the power of their technological mastery, threatened to burn down a village if its inhabitants refused to collect wood for the expedition. ${ }^{26}$

If the numerous expeditions across and through Africa were a symbolic expression of the reality of colonial domination in physical form, it is also true that motor vehicles are by nature transient objects. That is, though symbolic domination could suddenly appear in a cloud of fumes and dust, it could also disappear across the horizon just as quickly. Clearly this had an effect upon the way in which inhabitants in the many African villages and cities viewed their first vehicles. ${ }^{27}$ However, the same was true for the colonial administrators themselves. ${ }^{28}$ Travel times decreased, travel discomfort decreased, and distances appeared to be smaller. Administrators could now complete in several hours journeys that used to take days, whereas the majority of their colonial subjects still spent days traveling on foot. That is, due to the introduction of motor vehicles into the colonial service, administrators' views of reality were substantially different from those of their subjects, and had changed from that which they themselves may have had prior to the advent of the car.

In addition to their usefulness in transportation, cars were and are fetishized material implements that could be used to impart or take away status and stature. Colonial officials complained bitterly that the provision of a motor vehicle was absolutely essential in the interests of their stature, and only secondarily in the interests of their work. ${ }^{29}$ The state itself used the provision of motor vehicles to impart status to those colonial subjects from whom it sought cooperation. Thus the new South African administration, seeking to impress Kaptein Vita, the warlord of Kaokoland, arranged for his transport to Windhoek in a motor vehicle..$^{30}$

Since cars were part and parcel of high colonialism, since they were intricately tied up with perceptions of status, no colonial official worth his salt would dream of arriving at settlements on foot. In other words, roads had to be constructed in order for officials to arrive in style. Or as Carol Summers has put it:

${ }^{26}$ BNA S 2/7/4, Kalahari Expedition, 1928, Official Report.

27 There is a classic photograph of a Tuareg woman begging for money from a motorcyclist in the Paris-Dakar rally. The futility of her begging is striking-for the rider will most certainly not be carrying any money with him, let alone CFAs-in that it so clearly epitomizes the separate worlds of perception in which these two people are living.

28 And obviously also for those who travel through the African country side in airconditioned vehicles. As a colleague once noted: "It's like watching a 3-D film."

29 Instances in which a car was acquired for its status as opposed to its usefulness is well illustrated by Alber, Motorisation, 5-7.

${ }^{30}$ NNAW, OCT 17, Telegram 28/5/17 Outjo Milpol to Windhuk. 
When cars and being white are so closely connected, few missionaries, government officials, or settlers would have wanted to end up walking the last few miles anywhere. They needed roads to allow stylish arrivals.... Cars decreased officials' need for labor in portering materials from spot to spot-instead the labor was invested in roads and their maintenance. ${ }^{31}$

Roads came to be constructed for status and symbolism as well as for purposes of logistics. 32

\section{New Legislation, Motor Transport, and Herero Mobility}

In the aftermath of the South African invasion of Namibia, new legislation was put into effect regarding access to and the occupation of land on the basis of racial and ethnic identity. Henceforth Herero were to be separated from Damara, and they in turn, being Black, were to be separated from everyone defined as white. In other words, henceforth one could gain access to land or be turned off land on account of the color of one's skin and the ethnic identity to which one had been assigned. ${ }^{33}$

A direct result of the new South African legislation was that intermixed communities that had lived together in relative harmony were literally torn apart. Herero and other Black African inhabitants of the territory were forced out of the central Namibian highlands and banished to live in newly established reserves on the perimeters of the territory. As the Herero reserves were established, the missionaries found themselves at a further remove from their flocks. Initially, they continued traveling by ox-wagon from farm to farm, now with more travel required to reach the reserves. Due to the greater distances involved and the ever-decreasing frequency with which they ministered to their congregants, the missionaries came to have less and less understanding of affairs in Herero society at large.

The extensive separation that had been brought about through the establishment of ethnically based reserves was also repeated on a far smaller scale in the urban areas. From one day to the next, missionaries discovered that their congregants had been expelled from the town and settlement centers of

${ }^{31}$ Carol Summers, personal communication via H-Africa@H-Net.msu.edu, 19/2/98.

32 An interesting aside at this stage is the case of a British colonial official in Tanganyika, who, wishing to live out the white dream in Africa, had hired a number of Chagga men to carry his belongings. The official was most put out when, instead of porting his goods on their heads, the men chartered a truck to transport the goods on their behalf. Personal communication, Stephen Rockel, 26/2/98.

33 Regarding race and access to land, see Fiona Adams and Wolfgang Werner, The Land Issue in Namibia: An Inquiry, Namibian Institute for Social and Economic Research, Research Report, 1 July 1990, Windhoek, 7-41. 
Namibia. Black inhabitants were expected to live in ethnically designated areas in Native locations set up on the outskirts of these towns and settlements. ${ }^{34}$ The new legislation affected the dead as well as the living. Henceforth inhabitants of Namibia's towns and settlements were to be buried separately in racially specific graveyards at some remove from the settlements and towns. ${ }^{35}$

Missionaries soon grew tired of slogging to and from the Native locations. Similarly Herero expelled from the centers of towns and settlements they had themselves established stopped attending churches now officially in areas beyond their jurisdiction. As Missionary Kuhlmann reported from Omaruru: "Unfortunately the way to the church has now become very far for the people; the location is about 2.5 to 3 kilometers away from the town, and the road is really sandy." ${ }^{36}$ Kuhlmann concluded that he could only visit the location in the early morning and in the evening. Consequently his contact with his congregants suffered, and as he himself admitted, Church attendance suffered.

During the course of the South African invasion of South West Africa in 1915, large groups of Herero and Nama, who had been deported southwards and northwards respectively by the German colonial authorities, started traveling back to their places of origin. In the conditions of anarchy so characteristic of war and in the uncertain South African military administration that followed, Herero men and women were once again free to move around and settle in the areas of their choice. The territory, which later became known as Namibia, was well known to them and Herero had contacts across its length and breadth. In other words, for Herero a trip from Windhoek to Keetmanshoop was not a step into the unknown. They had detailed knowledge of places they might never have visited before, and the idea of traveling from one spot to another was less daunting than it might have appeared to other pastoralists at the same time. ${ }^{37}$ That is, mobility, or rather awareness of the possibil-

34 Jeremy Silvester, Marion Wallace, and Patricia Hayes, "'Trees Never Meet' Mobility and Containment: An Overview, 1915-1946," in W. Hartmann, P. Hayes, J. Silvester, and M. Wallace, eds., Namibia Under South African Rule: Mobility and Containment, 1915-1946 (Oxford, 1998). VEMA RMG 2501 H. Rethemeijer, Halbjahresbericht der Station Gobabis, vom 1.7.-31.12.1934. Report that the location in Gobabis has been moved $2 \mathrm{~km}$ away.

35 VEMA RMG 2503 Grootfontein, 30.9.26, Bericht vom 11 juni bis ende September, 1926, Schmitz. Report that the native graveyard is new and far away from the place where the whites are buried.

36 VEMA RMG 2514b Kuhlmann, Omaruru 31.3.23, Bericht 1.10.22-31.3.23. JBG's translation.

37 Geert Mak, Hoe God Verdween uit Jorwerd: Een Nederlands Dorp in de Twintigste Eeuw (Amsterdam, 1996). Mak describes the somewhat limited perspective of village inhabitants in Friesland in the early twentieth century. 
ity of mobility, and the existence of contacts across space, had become an integral aspect of Herero society on account of the Herero-German war.

Even in the past there were individual Herero with a wider knowledge of the world. In 1836, a young Herero boy was purchased by Sir James Alexander for the princely sum of two handkerchiefs, given the name Samuel Shephard and taken to England where he was educated at Woolwich College. In the 1870s and 1880s Samuel Shephard and his descendants worked as the scribes and interpreters of the Herero chiefs in Okahandja. Interestingly, one of the most active and widely traveled of the Universal Negro Improvement Association (UNIA) activists in southern Africa in the early 1920s was Samuel Shephard's son Saul, who traveled from the Bechuanaland Protectorate throughout Namibia to the northern Cape of the Union of South Africa. ${ }^{38}$ Herero women such as Johanna Uerieta Gertze greatly assisted Missionary Hugo Hahn in learning Otjiherero (the Herero language); they also accompanied the Hahn family to the Cape and even to Germany. ${ }^{39}$ In the 1860 s Herero from central Namibia were accompanying missionaries and traders to the Cape. Most prominent of these Herero were Wilhelm Maharero, Michael Tjisiseta, Samuel Maharero, and Zacharias Zeraua, the sons of the various regional Herero chiefs, who were also taken to the Cape. With the advent of German colonialism in the 1880 s, numerous young Herero men were taken to Germany by Schutztruppe soldiers who had served in Namibia. In 1895, on account of a colonial exhibition organized in Germany, the sons of Michael Tjisiseta, Samuel Maharero, and Nicodemus Kavikunua were taken to Germany, where they held an audience with Emperor Wilhelm II and were put on display in Berlin. ${ }^{40}$

During and after World War I Herero returned to Namibia from all over southern Africa, and from Europe as well. ${ }^{41}$ The National Archives in Windhoek contain references to at least three Herero men who had traveled to France during the war as part of the South African war effort..$^{42}$ Thus those who returned to central Namibia had a wider view of the world than many other world citizens of the time. Herero returnees were aware of events and occurrences in Cape Town, Kimberley, and the South African Rand, the

38 Jan-Bart Gewald, Herero Heroes: A Socio-Political History of the Herero of Southern Africa, 1890-1923 (Oxford, 1999), 212 fn. 76. $56-64$.

${ }^{39}$ Brigitte Lau, History and Historiography: Four Essays in Reprint (Windhoek, 1995),

40 Gerhard Pool, Samuel Maharero (Windhoek, 1991), 39. Pool's book has a fine photograph of the young men in Germany taken at the time.

${ }^{41}$ See Gewald, Herero Heroes, 288-96; Werner, Herero, 82-109.

42 NNAW NAW 1, Reference to Herero Adam No. 7646 and August No. 7649, as having served in the Native Labour Contingent. 
largest urban centers in sub-Saharan Africa at the time. They knew about the existence of trade unions, African nationalist political parties, independently owned African-language newspapers, African clergy, and the presence of Africans working as train engineers, lawyers, medical practitioners, journalists, and much more. ${ }^{43}$ They recognized the differing forms of colonial administration in Angola, the Bechuanaland Protectorate, and the separate provinces of the Union of South Africa. New concepts of state, nation, identity, belief, and social relations had been experienced at first hand by large numbers of Herero, who had discussed and partially internalized the related concepts. It is probably on account of these first-hand experiences and wider perceptions of the world that the essentially foreign pan-Africanist message of the UNIA came to be so aggressively supported and propagated by the Herero of central Namibia in the early $1920 \mathrm{~s} .44$

By the time South Africa began to administer Namibia, travel and the concept of mobility were not foreign to the majority of the Herero. In contrast to what the new administration expected of their colonial subjects, Herero men and women were not averse to traveling throughout the territory by rail, oxwagon, and foot. Missionary Kuhlmann reported with ill-concealed disapproval in 1921 that due to the increase in wages, Herero were traveling by rail from Omaruru to Keetmanshoop, a distance of no less than 726 kilometers. ${ }^{45}$ Indeed the extensive traveling done by women would later be seen as the basis for moral concern. The establishment of native reserves at a great distance from the territory's main urban areas ensured that, partly out of necessity, traveling and mobility remained essential to Herero society. Herero men working in urban areas often converted their cash earnings into livestock holdings, which were confined by law to the territory's "Native Reserves." Thus if a Herero man wanted to keep an eye on his livestock, he would have to make an extended journey to the reserve to which he had been assigned. ${ }^{46}$ For some men such a journey could easily entail a one-way journey of no less than 500 kilometers. With the introduction of the motorcar, busses, and lorries into everyday life in Namibia in the early 1920s, Herero mobility, which had

43 J.-B. Gewald, "The Road of the Man Called Love and the Sack of Sero: The HereroGerman War and the Export of Herero Labour to the South African Rand," Journal of African History 40, 1 (1999), 21-40.

44 Peter Mühlbauer, Marcus Garvey's UNIA and Its Influence on the Otruppa Movement, paper presented at the "People, Cattle and Land: A Symposium on the Culture, History and Economy of Otjiherero Speaking People," Siegburg 14-17 September 1997.

45 VEMA 2514b, Omaruru, 30.9.21, Kuhlmann, Halbjahrsbericht (Vom 1 April bis 30 Sept).

46 For a discussion on the conversion of cash wages into reserve cattle, see Werner, No One Will Become Rich, 61-66, 97-100, and 158-60. 
grown by leaps and bounds in the first years of South African occupation, now increased to an even greater extent.

The introduction of the car, bus, and lorry made it easier for people to visit one another, and visit they certainly did. As with so much in the historical record, that which comes to attention is often the spectacular, and this is certainly no different with the Herero use of motor vehicles. From the mid1920s onward, missionaries regularly reported on groups of Herero who traveled from site to site in rented lorries bearing spectacular flags and banners. More often than not the people involved were members of the Otruppe on their way to and from Otruppe functions and commemorations. ${ }^{47}$ However, the reports also mention sports teams and mixed groups of men and women bearing flags on their way to various venues across the length and breadth of the territory. The words of Missionary Kühhirt, bemoaning the absence of Herero congregants from his church, gives a fine description of the use of motor vehicles by Herero at the time:

Often they make big excursions [Ausflüge] with hired lorries. They have been at the inauguration of a gravestone of a chief in Omaruru, at the commemorative celebrations at the grave of their chief, Samuel Maharero in Okahandja, and now they were driving in fine military dress with flags on two trucks to Otjizeva, where with ceremony they would place a cross on the grave of a dead comrade. They also often make journeys of which I know nothing. They need a lot of time and money for this. To church they only come on Christmas, New Year's, and Good Friday. 48

The sight of trucks filled with Otruppe racing along with flags and banners braced against the wind must have been striking. Certainly the missionaries thought so, and undoubtedly this was precisely what the troop members were aiming at. The arrival of a truckload of football players from Karibib, bearing flags in the "colors of the Ethiopian freedom movement," was enough to disrupt Sunday service and certainly helped score some moral points off the Otjimbingwe home team. ${ }^{49}$

${ }^{47}$ Following the defeat of the German army in Namibia in 1915, Herero associated with the Germany military established the Otruppe, a self-help paramilitary organization modeled on the Germany army. The settlers called them Truppenspieler (or "soldier players"). See Wolfgang Werner, "'Playing Soldiers': The Truppenspieler Movement Among the Herero of Namibia, 1915 to ca. 1945," Journal of Southern African Studies 16, 3, 476-502.

48 VEMA, RMG 2533 c, Windhoek, 1929-1945, 1.10.29-31.3.30, Halbjahrsbericht, Kühhirt, Windhoek.

49 VEMA RMG 2536, Halbjahrsbericht über die Missionsarbeit auf Otjimbingwe, November 1927. 


\section{Cars and Status}

The Herero were also aware of the status that could be imparted through the use of motor vehicles. The missionary in Otjimbingwe noted that it was the "progressive youth" within the community who were associated with the banner-clad lorries. Clearly the Herero Otruppe, as with their German Volksverein (people's association) ${ }^{50}$ compatriots, used their gaily decorated lorries and trucks to improve their own status as well as to make a statement regarding both the sociopolitical situation in which they found themselves and their own modernity as vibrant human beings in tune with the technological age..$^{51}$ It is striking that in the late 1930s, when the majority of the settlers of German descent had thrown in their lot with the Nazi party, the Nazis of Windhoek were organized into motorized units that patrolled the streets of Windhoek when they saw fit to do so. ${ }^{52}$ It is even more striking that motor vehicles have come to play such a central role in defining the historical image of such an organization. Similar scenes of marching, uniformed, and motorized masses also dominate our images of the Herero past. Missionary Olpp referred to this phenomenon in the following manner:

There is hardly anything that the Blacks did not attempt to imitate from the Whites. They have seen something of Boy Scouts and Girl Guides with flags and uniforms, and immediately they wish to have the same in their form. They see how the Whites celebrate and have remembrance days for the battles for Okahandja, the relief of Omaruru, the massive battle of the Waterburg, and so forth. Now they do the same with remembrance days for their former chiefs and leaders. Yesterday, on Sunday, there was a car here from Karibib. They came to give the last military honors, as they have seen the Whites do, to the son of a leader who lies buried here. They arrived in the short kilts of Scottish highlanders and one proudly wore a black, white, and red sash. Such copying may appear childish to us; it is proof, however, ... that here a people is awakening, is rising up from its lack of history, and is

50 The German term Volk (people) has to be seen in the context of the 1930s, where the term implied specific ideas regarding language, culture, and race.

51 Thus an edition of Der Reiter von Südwest carried an article based on "The travel log [Fahrtenbuch] of our youngest." The article, which is written in the terse style of a military communiqué, contains photographs of trucks carrying young flag-carrying German settler children dressed in uniforms based on those of the Schutztruppe, engaged in playing war games. Der Reiter von Südwest, December 1927, 10.

52 Bundesarchiv Potsdam, PTS 2088, Allgemeine Angelegenheiten von DeutschSüdwestafrika, vom Juli, 1914 bis März, 1939, v. Oelhafen, Windhoek, to Deutsche Gesandschaft Pretoria, 13.12.38. 
searching for the forms it needs to ensure that it and its race will also gain recognition from the Whites. ${ }^{53}$

In contrast to his contemporaries, Olpp saw Herero actions as being more than the mere aping of German activity. Though one may not agree that Herero "sought forms with which to gain recognition [solely] from the Whites," Olpp's words indicate that the use of cars, uniforms, commemorative ceremonies, and the like were forms that could be used to gain recognition. These were all social markers and indicators of the modern world. Herero strove for access to and mastery over these forms precisely because they were modern, and allowed their masters to claim that identity.

The skills necessary for driving a motor vehicle are not determined by race. In Namibia of the 1920s and '30s, however, race determined the wages paid to drivers. In contrast to the railways, where a strong trade union tradition ensured job reservation on the basis of race, there was no form of organized worker opposition that could prevent the owners of transport and haulage companies from employing cheaper black labor. ${ }^{54}$ As a result truck drivers in Namibia of the 1920s and '30s could be Herero or Baster men. Apart from enjoying the status associated with those who controlled the juggernauts of modernity, these men also came to form the backbone of a nationwide informal information network. Events in the country's towns, villages, and farms came to be reported by eyewitnesses who had driven their loads across the land. This was similar to periods when Herero and Baster men dominated the ox-wagon trade, except that now events in Keetmanshoop in the south, or Omablantu in the north, were discussed in Windhoek with those who had witnessed events two days earlier. Windhoek, and the Herero drivers who resided there, came to form a hub through which information radiated throughout the territory. Those who controlled and drove these new forms of transport gained status as the purveyors of knowledge as well as the masters of materialized modernity.

Others also sought to use motor vehicles specifically for the status they conveyed. When officials provided Friedrich Maharero with a motorcar for his travels to Gobabis in the early 1920s, they certainly bestowed status upon him and his companions, but they also raised the hackles of men such as Missionary Irle who believed that cars should never be placed at the disposal of blacks. ${ }^{55}$ Black members of the Windhoek location advisory board used taxis

53 VEMA RMG 2693, Zusammenfassender Bericht über die Missionsarbeit in Südwestafrika im Jahre, 1929, J. Olpp, Swakopmund, 18.12.1929. JBG's translation.

54 This would change in the 1940s when the South African Railways, and thus white trade unionists, gained a monopoly over the road transport and haulage businesses.

55 VEMA RMG 2501, Irle, Bericht über die Gobabischer Gemeinde, IV Quartal, 1923 und I Quartal, 1924. 
at a time when the majority of Namibia's population, white or black, could not afford to do so. Advisory board members used taxis to indicate their position and status, and were most upset when events occurred that in some way detracted from these. A fine example of this is provided by advisory board member Kapuuo, who, in a discussion on children's truancy, noted the following:

There is heavy motor traffic in town and children are in danger of being run over; they have no fear of motors and find pleasure in seeing how near a moving car they can get; this of course is natural to children. If I take a taxi to Klein Windhoek and imagine I am the only passenger I find on looking round 6 to 8 piccanins perched behind. They board the car in motion, which is dangerous.... ${ }^{56}$

Certainly jumping on a moving car was a dangerous habit, but what is particularly striking is Kapuuo's reference to his ability to charter a taxi solely to transport one person to one of Windhoek's locations, when cheaper forms of transportation would have been available. Kapuuo's statement was made in the middle of the Great Depression, a period when few people could afford a taxi. Indeed in Windhoek at the time work-for-food programs were the order of the day for both black and white. It is safe to say that, whether consciously or not, Kapuuo sought to draw attention to his financial (and thus social) standing, as a man who could afford to hire taxis. His statement is interesting because in it he emphasizes his ability to purchase seclusion and status, as opposed to congregation and anonymity. In other words, through paying an exorbitant taxi fare Kapuuo expects, and is able, to purchase two attributes of the modern world, privacy and the motorcar, both attributes that serve to emphasize his status as a member of the elite.

Beyond the use of motor vehicles for sociopolitical posturing, motor vehicles bestowed a new form of status upon those who rode in, controlled, and drove these new forms of transport. ${ }^{57}$ As noted above it was with resentment and envy that Missionary Irle mentioned that the government had supplied Friedrich Maharero and his compatriots with a car. It would take another ten years before Irle's superiors would be prepared to supply him with one..$^{58}$ Interestingly, though it was not something that Irle appeared to realize at the

56 NNAW, NAW 29 Advisory Board Minutes, Office of the Superintendent of Locations Windhoek, 25 August 1931. Emphasis added.

57 In addition we must not forget that new ways of looking at the world and dealing with distance had to be learned in order to drive a motor vehicle. Sites of ritual importance suddenly came to be much closer to one another, for example. In short Herero perceptions of the world changed dramatically.

58 VEMA RMG 2501, Irle Gobabis Anfang Mai, 1924, Bericht über die Gobabischer Gemeinde, IV Quartal 1923 und I Quartal 1924. 
time, Friedrich Maharero's access to a car ensured that he was not overly dependent on those he chose to visit for food, shelter, water, grazing and the like; no longer dependent on animal transport, it was not necessary for him to spend more than a few hours visiting. Thus, in a sense, Irle's pique at not being graced with a longer visit mirrored what would later happen to Herero when missionaries were supplied with cars. Irle was aware of the status that access to a car had bestowed upon Friedrich Maharero, an awareness that Herero elites attempted to expand upon in efforts to improve their standing vis-a-vis the colonial state.

The social status accorded to those who could purchase or acquire the services of motor-driven vehicles was also in part imparted to those who drove, maintained, and repaired these new vehicles. A new class of skilled professionals developed-drivers, mechanics, mechanical assistants, pump attendants, and the like, capable of dealing with the vicissitudes of the new mode of transport. Oral testimony indicates that Herero drivers, particularly for German-owned businesses in the territory, were considered to be highstatus professionals. Indeed, drivers' names came to be conflated or combined with the brand names emblazoned on the doors or hoods of the trucks they drove. 59

\section{The Disadvantages of Motor Vehicles}

Though the introduction of the motor vehicle entailed the opening of new opportunities, as well as social and financial profit for many, it also meant the physical, economical, and social ruin of many of Namibia's inhabitants. Negative aspects of the introduction of the motorcar for the Herero in central Namibia included the physical danger posed by the new technology. Kapuuo referred to the dangers posed to those who failed to take account of the speed and force with which motor vehicles were driven. With numerous people making use of the new technology to visit friends, events, commemorations, and the like, it was inevitable that fatal accidents occurred. Missionary Pardey provides us with the description of an accident in 1937, which, but for the fact that it took place over sixty years ago, could be used to describe similar occurrences today:

On the 26th of August teacher Bartholomeus Hanavi from Grootfontein was involved in a fatal accident at [the farm] Sukses while traveling to Okahandja. The government had called upon the Herero to participate in the big meeting of the Herero in Okahandja on the 28th of August (Samuel Maharero's date of death). From Grootfontein about fifty wanted to travel to Okahandja. They hired two big trucks for themselves and set out from Grootfontein in a merry mood on the

59 Personal communication, Immanuel Tutonderumbi. 
morning of the 26th of August. Near Sukses (between Otjiwarongo and Okahandja) the vehicles came across a herd of cattle, which did move away, but one ox crossed the road between the two trucks, and this proved fatal to the second truck. The truck driver attempted to avoid the ox, but made too sharp a turn, so that the truck rolled twice on account of its great speed. Bartholomeus Hanavi, a Herero woman, and the nine-year-old child of one of the drivers were immediately killed. ${ }^{60}$

Apart from the loss of life, the large-scale and rapid introduction of motor vehicles following the First World War ensured that numerous people involved in the transport business, which had been wholly based on animal traction, were put out of a job. A series of Baster families had dominated the transport business in Namibia until the early 1920s; Herero transport drivers, who had been concentrated around the settlements of Kalkrand, Omaruru, and Otjimbingwe had been annihilated in the Herero-German war. During this war the Baster families, whose operations had earlier been confined to the area south of the Swakopmund Karibib Windhoek railway line, had expanded their operations northwards in support of the German armies to whom they had been commissioned. An exception had been the family of old Chief Joseph Hameba of Gobabis who, although a Herero, had survived the Herero-German war through riding transport for the Germans. Indeed so successful had Joseph been that after the war he and his followers were awarded land in the vicinity of Gobabis. ${ }^{61}$ Along with many Baster transport riders and their employees, Chief Joseph was finally put out of business by the introduction of the motor vehicle, the onset of the Great Depression, and the beginning of a six-year drought in 1928. Samuel Cohen, who had made a fortune selling cars in Namibia, noted that at the time he was prepared to barter cars for supplies of wood and salt, with which Baster families sought to accomplish the changeover and continue their transport businesses. Some transport riders appear to have successfully accomplished the changeover, but the number of employees needed would still have decreased substantially. It is likely that those Herero living in the area administered by the Baster Council of Rehoboth and working as transport riders for Baster contractors found themselves without any form of employment.

60 VEMA RMG 2503, Pardey, Jahresbericht Grootfontein, 1.1.-31.12.37. JBG's translation. Given the condition of the roads at the time, the trucks must have been traveling at quite some speed to become involved in the accident described, particularly when one considers that the drivers had evidently already slowed down for the cattle herd that had crossed their path.

61 Relations between Joseph and the Germans later soured, and in 1914 he and his followers sought asylum in the Bechuanaland Protectorate. BNA, RC 10/18, British Consulate for GSWA in Luderitzbucht, 29/6/14, to the Secretary for Native Affairs in Cape Town; and NNAW, SWAA 2081, A 460/5 Gobabis, 1918-1951, Report on Working of Native Locations Gobabis, 1918. 


\section{Cars and Farms}

Together with subsidized fencing and drilling programs, the introduction of the motorcar ensured that labor relations on the white-owned stock farms in central Namibia changed completely. With the introduction of fencing and the division of stock farms into stock camps divided by a series of fences, each with its own watering point, the amount of labor needed by a farmer to control his stock decreased dramatically. In addition, white ranchers did not concentrate on the production of dairy products, choosing instead to concentrate on beef production, which was far less labor-intensive. The introduction of motorcars to the farms required that roads, or rather tracks, be laid out across the farms to enable a farmer to visit the furthest reaches of his farm and back within the course of a day. The rapid developments brought about by the First World War in the motor industry meant that in the first decade after the war reliable mass-produced and relatively cheap motor vehicles were available. Although Namibia's settler farmers were initially slow to accept cars, by the second half of the 1920s motor vehicles had become indispensable tools for farming in Namibia. ${ }^{62}$

Together with subsidized fencing, subsidized drilling for water, protective tariffs, and a series of financial incentives, motorcars transformed the face of settler farming in Namibia. Subsidized fencing and subsidized drilling for water meant that farmers could divide their sprawling ranches into compartments (or camps) centered on watering points. Not only did the camps permit the farmer to better control the grazing and watering of his herds, they also reduced his need for labor. The fences effectively did away with the need for extensive herding. Henceforth gates and motorcars helped controlled the movement of cattle. Similarly, the subsidized pumps did away with the need for extra labor for the express purpose of watering. Farm laborers, their numbers already substantially reduced on account of the fencing, could be transported quickly to all corners of the farm, ensuring that even fewer laborers would be necessary. The missionaries operating in central Namibia at the time were acutely aware of this process as it was taking place, and provide us with some first-hand insights into what was going on.

In 1927 Missionary Irle, operating out of Gobabis, reported to his superiors how difficult it was to preach to farm workers, as most were out fencing; coupled with the arrival of the car, fencing had driven most of the Hereros off the farms. Reporting on the farms along the Windhoek to Gobabis road, Irle noted:

Remarkably it appears that the Natives in increasing numbers are withdrawing from these farms, even though only the original founding

62 Gordon, Picturing Bushmen, 101-102. 
German family lives there. Partly this is probably due to the farmers having fenced in their farms and as a result they do not keep more laborers than is absolutely necessary for the farm work. On the other hand the car has appeared on nearly all the farms, and as a result some of the labor has become redundant. All of this contributes to a situation in which, in comparison with the past, one finds ever fewer Natives....63

Armed with their motor vehicles the farmers no longer needed the services of those people from whom they had wrested the land in the past. Henceforth all non-essential Herero were expelled from the farms.

\section{Missionaries and Mobility}

The first missionaries to enter Namibia did so either on the back of an ox or accompanied by ox-wagons; thus the maximum speed at which they could travel was determined by the speed of the oxen. The successful handling of an ox-wagon depends upon a number of highly skilled and structured occupations, something missionaries could not hope to accomplish on their own. Like all other animals, oxen need food, water, and rest, and thus journeys had to be organized in such a manner that these needs were met. Thus trekking was only done in the cooler hours of the day, or at night. Treks were generally from one water source to the next, failing which "thirsts" 64 would be covered through complex leapfrogging whereby a wagon would be lugged across part of the "thirst" and the outspanned oxen either driven ahead or behind to the closest water source. Oxen would generally be allowed to graze and ruminate during the night and heat of the day; when the driver wanted to span the oxen, he would have to rounded them in the veldt and drive them back to wherever the wagon had been left standing. In other words, traveling by ox-wagons was very labor-intensive. A wagon would always be accompanied by a number of people, either directly employed in the running of the wagon, or as a cluster of followers who chose to accompany the wagon for guidance, support, safety, and company through the veldt. Today the trip from Windhoek to Gobabis can easily be accomplished in two hours, but a journey by ox-wagon could take ten days or more. Thus ox-wagons and their retinue formed small social islands that slowly traversed the veldt. Missionaries journeying from Point A to Point B could not help but become directly involved with their fellow travelers.

${ }^{63}$ VEMA RMG 2501, Irle, Halbjahrbericht Gemeinde Gobabis, 1 April, 1927-30 Sept, 1927. JBG's translation.

64 The term "thirst" was used in southern Africa to refer to a stretch of territory to be crossed by ox-wagon, but in which no water was to be found. 
In his excellent history dealing with the Xhosa "Cattle Killing" of 1856-1857, Jeff Peires describes the close relationship that developed between Nathaniel James Merriman, Anglican archdeacon of Grahamstown, and his personal servant Wilhelm Goliath Mhlakaza. When Merriman arrived to take up his position in Grahamstown, he took to walking, accompanied by Mhlakaza, throughout the districts where he supervised the Anglican Church. Over a period of a year and a half the two men tramped all over the eastern Cape, journeys in which the two men came to know one another particularly well. Peires noted that the long walks afforded the two men with an opportunity to talk religion: "and the archdeacon's journal paints a near-idyllic picture of two Christian comrades immersed together in the study of God's word." 65 In addition Mhlakaza came to act as an interlocutor not only between Merriman and the Xhosa, but also between mission Christianity and Xhosa epistemology: "Some times, he sat up deep into the night talking Christianity with his fellow blacks long after the archdeacon had retired to sleep."66

The words of Missionary Pönnighaus also provide a fine indication of what it was like to travel extended distances at walking speed. Pönnighaus traveled through central Namibia by ox-wagon in the early 1920s:

It is already the eighth day in the ox-wagon. This morning we had our last glimpse of the massive rocky chain of mountains of the Auas in the far west.... Hearty handshakes and happy waving....

The [path] leads into the fresh morning and fresh grass. Still women and men hurry to our white-tented wagon and stretch out their black and yellow hands in farewell greetings. A black Bergdama from Otjimukona, who was married yesterday evening, hurriedly comes riding along from more than an hour away and brings another pound with which to pay his churchly dues for a number of years,...

The grass becomes higher. The wheels deeply plough through the yellow sand.... a mighty tree beckons. Here we outspan. The jackets are hung in the branches above us. Kindling is in ample supply. On the back of Michael, Hermann [the missionary's five-year-old son] is carried across a patch of devil thorns.... Everybody gathers around the coffee kettle and the stew pot. Whilst the oxen graze in the tall grass

65 J.B. Peires, The Dead Will Arise: Nongqawuse and the Great Xhosa Cattle-Killing Movement of 1856-7 (Johannesburg, 1989), 32.

66 Ibid., 78-81. Peires hints that Mhlakaza's association with Merriman led in part to the "Cattle Killing." Nongqawuse, the prophetess who convinced the Xhosa that their ancestors would return, was the niece of Mhlakaza, and lived with him following his break with Merriman. Nongqawuse told her uncle of the strangers she had met who had called upon the Xhosa to kill their cattle. Mhlakaza was instrumental in getting the chiefs to accept the prophecy. 
and are nearly lost from view, the missionary fills out marriage certificates and sorts out his community cards. ${ }^{67}$

During the course of weeks and even months that missionaries were involved in their field trips, preaching and ministering to their far-flung congregants, they formed close, intense, and occasionally difficult relationships with those who accompanied them. Wagon drivers, herders, touwleiers, ${ }^{68}$ and others, heathens in the eyes of the missionary, became distinct individuals with distinct personalities, characters, and histories. Missionary Pardey, operating out of Grootfontein in the early 1920s, provides an illuminating glimpse of the conceptualizations and conversations that developed during these journeys:

The third salaried evangelist of the mission is Immanuel Kauetjesa. He lives in Grootfontein and is, in the first instance, my driver [!], however he also visits some of the farms. He is tranquillity personified, a real Herero, who does not over-exert himself.... During a farm journey he asked me what language had been spoken by people in paradise. When I told him that this could no longer be determined, he declared that this must have been the Herero language, because all the Natives who came to South West Africa communicated in this language. ${ }^{69}$

Particularly in those instances where the missionary's language skills were underdeveloped, the people who accompanied the missionaries on their journeys mediated and interpreted for people they encountered in ramblings across the veldt. Trekking groups took on distinct personalities and idiosyncrasies-essentially the sum of the personalities of the travelers-that determined the missionary's view of the people and societies he happened to come across in his journeys. Numerous missionary accounts recall going to sleep to the sound of the wagon's retinue discussing the day's events and chatting to those whom they had encountered during the day. Numerous accounts describe missionaries being awakened by the sounds of visitors who had come out of the veldt to talk to the trekking retinue. Whether he liked it or not, the missionary would almost continuously become part of a running commentary on the landscape and societies he happened to be traveling through. These views colored the manner in which the missionary thought of and dealt with the people he came across in his travels, and obviously they also shaped the

67 VEMA RMG 2635b, Taken from an essay entitled "Unterwegs," written by missionary Pönnighaus. Folio 57. JBG’s translation.

${ }^{68}$ A touwleier ("rope leader") was the person at the head of a span who led the oxen forward.

69 VEMA RMG 2503 Pardey, Grootfontein, 1 October 1924, Halbjahrsbericht. JBG’s translation. 
texts he chose to commit to paper in journals, letters, reports, and sermons. All of this changed with the widespread use of the motorcar into the service of missionaries operating in central Namibia.

\section{The Disadvantages of Wagons}

For all of its idyllic qualities, travel by ox-wagon was totally dependent upon a number of natural factors, over which even the most faithful of missionaries had but little control. Whether they liked it or not, the users of ox-wagons were always limited by the availability of adequate grazing and water. Another factor that started to weigh heavily upon the missionaries by the early 1920s was the issue of time. With their congregants dispersed to the four corners of the territory on account of the new reserves, missionaries increasingly came to bemoan the extremely long time they were forced to spend in their travels. In the past, everyone who sought to travel through the territory was limited by the same constraints and the limits did not become an issue. But with the coming of motor vehicles and the proven effectiveness of the new technology, the missionaries could not help but call for the issuance of motorcars to themselves. With the knowledge that more efficient form of transportation was available, one that appeared to be more suited to their purposes, it is hardly surprising that almost all missionaries began to call for motor vehicles with which to conduct their work.

In a series of letters, individual missionaries working in Namibia complained of their lack of motor vehicles. Missionary Kühhirt, for instance, simply noted that he had not visited any of the reserves, where most of his congregants were living, as he considered them to be to far away to travel to without a car. ${ }^{70}$ Missionary Pardey, although he complained that it took him at least five days to visit the reserve at Otjituo, held out the promise that with a car he would be able to visit two to three places in a day within the reserve. ${ }^{71}$ Venerable Missionary Kuhlmann, operating out of Omaruru, complained of his age, bouts of malaria, and the absence of sufficient grazing: "The further I entered the reservation, the more extreme the absence of grass became, ... I refused to give up. With great difficulty we reached still another place. However, the stock and the people returned to where we had come from for feed and water, and that was about 20 kilometers." 72 Kuhlmann's words mirrored those of Missionary Rethemeijer, who operated out of Okahandja. In a report for the second half of 1929, Rethemeijer stated that he had hoped to visit his congregants at the outlying farms and reserves, but that "It is impossible to

70 VEMA RMG 2510, Kühhirt Halbjahresbericht Okahandja, 20/9/25.

71 VEMA RMG 2503, Grootfontein, 3/4/29, Pardey, Bericht vom 1 Okt. 28-31 März 29.

72 VEMA RMG 2514b Kuhlmann, Omaruru, 31/3/23, Bericht 1/10/22-31/3/23. JBG's translation. 
cross the dry belt that has been laid around Okahandja with oxen, as they will probably remain lying down half-way through." 73 Under these circumstances, it is hardly surprising that Rethemeijer also submitted an urgent request for a motor vehicle. The missionaries were emphasizing that cars did not depend on grazing and water, and were faster.

\section{The Use of Cars by Missionaries}

A host of other factors related particularly to cost and status were also important in insuring that cars and trucks came to replace the ox-wagon in missionary service. Once equipped with a car, missionaries did not need to employ a retinue of assistants to ensure the successful completion of their journeys. They no longer had to pack provisions for up to twenty people for anything between 30 and 100 days. Spans of up thirty oxen no longer needed to be watered, fed, or tended to, let alone purchased or rented. Missionaries no longer needed to pack seemingly endless supplies of coffee, tea, sugar and tobacco with which to pay for the goodwill of Herero settlement heads with whom they and their retinues would stay. In all, the motorcar was simply more cost-efficient. There was also, however, the more sensitive issue of status.

In 1929 Missionary Pardey returned to Namibia following an extended holiday in Germany. Almost immediately upon returning to his post, he submitted an urgent request for a car. ${ }^{74}$ Reading his reports, one would almost be convinced that in his absence all the white inhabitants of status in Grootfontein had acquired motor vehicles. Naturally therefore, he, as the resident missionary, could not allow his status to fall below that of his peers. ${ }^{75}$ In other quarters of Namibia, missionaries complained, not only of white settlers and colonial officials as being equipped with cars, but more particularly of their arch-rivals, the Catholic missionaries, as having been equipped with cars. ${ }^{76}$

By the early 1930 s cars were being issued to the missionaries. ${ }^{77} \mathrm{~A}$ direct result was that missionaries literally spent their time zooming around the countryside. Henceforth missionary reports change in content, and extended

73 VEMA RMG 2510, Halbjahresbericht der Station Okahandja vom 1/10/29-31/3/30, H. Rethemeijer. JBG's translation.

74 VEMA RMG 2503, Grootfontein 3/4/29, Pardey, Bericht vom 1 Okt. 28-31 März 29.

75 Pardey actually received his car in early 1930. VEMA RMG 2503, Grootfontein, 2/4/30, Bericht vom 1.10.29-31.3.30.

76 VEMA RMG 2501, Irle, Halbjahrbericht Gemeinde Gobabis, 1 April 1928-30 September 1928.

77 Rob Gordon has noted the remarkable increase of cars in Namibia at the time: "The first light American cars were introduced in 1913, and by 1929 the mandate, it was said, ranked 'amongst the countries which possess the greatest number of cars per head of [settler] population'." Gordon, Picturing Bushmen, 101. 
discussions on the social, ecological, religious, and political conditions of the trek are replaced by short anecdotes about people and settlements seen in a glimpse.

The missionaries soon discovered that the possession of cars had negative aspects as well, ranging from the banal and blatantly obvious to the more portentous and subtle. Surely one of the more banal incidents of missionary history in Namibia is the sunstroke suffered by Missionary Rethemeijer, who drove to and from a farm funeral on a fine summer day with the roof down, shortly after taking delivery of his vehicle. ${ }^{78}$ Missionary Werner's struggles with a river in flood have already been described. His sorry situation was later mirrored by fellow missionary Tschäschke. While the latter was driving through the Aminuis reserve in 1933, his half-ton Chevy started overheating and finally broke down. Though Tschäschke appealed for help from Herero settlements in the area, no one was prepared to assist him except in exchange for a substantial amount of cash. ${ }^{79}$ Since missionaries expected to be treated with respect and hospitality, such situations sometimes poisoned their views of the people they hoped to convert. The introduction of the motor vehicle into missionary service had clearly changed Herero attitudes towards the mission.

In the past, when the missionaries were conveyed by ox-wagons, it was customary for them to outspan at large shady trees in the immediate vicinity of Herero onganda, or family settlement. This custom changed with the introduction of motorcars into missionary service. Missionary Pönnighaus reported of a visit to the Okakarara reserve in 1934, that: "In Otumborombonga we were not allowed to camp with the car under the beautiful and shady Omusauna tree at the cleaned space at the entrance of the settlement. Nikodemus Vesevete, an Omaruru Christian, the brother of the foreman Engelhard, drove me forth." 80 Instead, Pönnighaus and his vehicle were assigned a spot where the "chicken and the dogs scratch around" ${ }^{81}$ Whereas in the past, the missionary and his retinue could count on the hospitality of those they visited, the introduction of the motor vehicle created such a distance between missionaries and Herero that most Herero would rather have the missionaries and their vehicles at some remove from their settlement. ${ }^{82}$

78 VEMA RMG 2501, H. Rethemeijer, Jahresbericht, Der Station Gobabis, 1.1.--31.12.1936.

79 VEMA RMG 2501, Halbjahrsbericht 1.7.-31.12.33, Tschäschke Gobabis.

80 VEMA RMG 2510, Im Reservaat Okakarara, 11/9/34, F. Pönnighaus. JBG's translation.

${ }^{81}$ Ibid.

${ }^{82}$ To what extent this aversion towards vehicles is to be explained by the factors referred to by Luise White is debatable, but worth bearing in mind. See the following footnote. 
Elsewhere Luise White has written on motor vehicles in the East and Central African context. Essentially White argues that the closed nature of the motor vehicle-with its private and inaccessible spaces-allowed for the development of all manner of ideas regarding its actual function. ${ }^{83}$ Since the introduction of the motorcar greatly reduced the number of people who traveled with a missionary on his rounds, knowledge of exactly what was to be found inside that car was greatly reduced. From one day to the next, people's knowledge about missionaries greatly decreased. In the past the missionaries had traveled, worked, lived, and slept inside wagons, open and accessible to all, albeit through the medium of the missionary's traveling companions. With the introduction of the car, the missionaries traveled in small containers of metal and glass, cut off from the world. No longer was the private space of the missionary knowable to those who were interested. Instead the missionary was effectively shut off from the world, and increasingly missionaries appear to have desired to shut themselves off from the world.

The case of Missionary Irle, who operated out of Gobabis, is a fine example of these issues. In the latter half of 1928 Missionary Irle traveled to Epukiro reserve by car. After a hard day's driving, he arrived at the settlement of one of the brothers of the late Samuel Maharero, Traugott Maharero, who had recently arrived in the area. Irle reported of Traugott that:

$\mathrm{He}$ is completely Herero, even if it is in a modern version. There he strode the lofty paramount, surrounded by his paladins. Missionary? Pah!! What is missionary?! Not a glance, not even a greeting is he worth. "You wish to preach God's word?", asks one of his paladins. "No need! Go forth! We have our Okuruuo [holy fire]." 84

Rebuffed by Traugott, Irle parked his car at a distance from the settlement and settled down to read the scriptures by torchlight as a cold wind buffeted the car. As he read, Irle was disturbed by a child knocking on the window. The child said he had been sent to call Irle. The settlement's inhabitants had gathered together in a hut and wished him to come and preach to them. Dressed in his jacket and shivering with cold, Irle set off towards where he believed the huts to be. Finally, after moving from door to door, Irle stumbled across a Herero evangelist who told him that it was far too cold for the people to gather

${ }^{83}$ Luise White, "Cars Out of Place: Vampires, Technology, and Labor in East and Central Africa," in Frederick Cooper and Ann Laura Stoler, eds., Tensions of Empire: Colonial Cultures in a Bourgeois World (London, 1997), 436-51. With thanks to Filip De Boeck, who kindly drew my attention to this article.

84 VEMA RMG 2501 Gobabis, Irle, Ende März, 1929, Halbjahrbericht. JBG's translation. The okuruuo was a particular ritual fire kindled in homesteads. The fire and everything associated with it were believed to embody aspects of ancestral and ritual importance. 
together for a church service, and that he had been fooled; people had merely wished to lure him away from his motor vehicle. In the event, Irle hurried back to his car to find that nothing had been taken. Interestingly, he later discovered that the child who had been sent to lure him away from his car had come from the settlement of Traugott Maharero.85 The example of Irle's car and Traugott's diversion is interesting precisely because it dramatically brings to the fore the way missionaries desperately tried to impose upon their vehicles the same privacy they expected of the private spaces in their own homes. ${ }^{86}$ That is, the cars became by extension transferable pieces of private space, much as if they had taken their own private offices and placed them on wheels. At the same time, this incident indicates that the Herero would seek various means to discover what it was the missionaries sought to hide in their cars.

The missionaries initially lauded the coming of the car. However, cars could get hopelessly bogged down in sand in the absence of the large traveling parties associated with the wagons. Though cars did not need grazing, they did need fuel, and it was not long before missionaries started canceling trips on account of the absence of fuel.$^{87}$ Even more extreme in impact than these two examples was the fact that, through the introduction of the car, missionaries had placed themselves at a further remove from their prospective converts and congregants. Instead of being forced to become acquainted with a multitude of traveling companions, missionaries could now move quickly from one settlement to the next. The multitudes became mere caricatures, and preconceived ideas about those to whom they wished to preach became further entrenched as they hurried on to the warm beds of settler farmers on the outskirts of the Herero reserves. ${ }^{88}$

In all, the introduction of the car into missionary service led to a dramatic decline in the level of information and understanding that missionaries (and, by extension, historians working with missionary sources) had of Herero society in central Namibia in the 1920s. In the mid-1920s a sudden and dramatic decline occurred in the content and quality of the missionary sources available. The decline was clearly staggered and linked to the timing of the introduction of the motorcar in missionary activities. Prior to the South African invasion,

85 VEMA RMG 2501, Gobabis, Irle, Ende März, 1929, Halbjahrbericht.

86 See the reaction of missionary Irle to the arrival of Herero at his house in Gobabis. VEMA RMG 2501, Irle Gobabis Anfang April, 1921, Bericht über das IV quartal, 1920 und das I quartal, 1921; and Irle Gobabis Anfang April, 1925, Halbjahrbericht über die Arbeit in der Gemeinde in Gobabis, Anfang Okt. 1924 bis Ende März, 1925.

87 VEMA RMG 2501, H.K. Diehl, Jahresbericht, 1939, Okahandja.

88 A fine example of this was missionary Irle, who planned his meals with settlers on the outskirts of the reserve. VEMA RMG 2501, Gobabis, Irle, Ende März, 1929, Halbjahrbericht. 
missionaries used to engage in wagon tours among their congregants living and working on the farms of their district. During these tours, which in some instances could last up to three months, the missionaries would minister to their scattered congregants and conduct marriages, baptisms, and confirmations. ${ }^{89}$ The missionaries could rely on the farmers to ensure that their laborers would pay their church dues and come to the church services organized by the visiting missionary. Herero living on settler farms were to some extent dependent on the support of missionaries vis-à-vis the settlers. With the imposition of the new South African administration, the majority of the Herero left the farms and settled on the reserves, where they had little need of missionaries, let alone any desire to pay their church dues. The introduction of the motorcar meant that the close link between missionaries and their fellow travelers, and thus their understanding of local events, ended abruptly when the missionaries were able to complete trips that had previously taken weeks by wagon, in a number of days. As Missionary Pardey in Grootfontein stated after he had taken delivery of his car: "In the past I needed 5 days for a trip to Otjituo; now, if the people have been warned beforehand, I only need one."90 As a consequence the missionaries had less intensive contact with those they traveled with and thus less detailed information to report on events and situations encountered during the course of their trips. In those instances where the missionaries suffered mishaps with their cars due to flooded rivers, breakdowns, sandy riverbeds, and the like, there was an inverse increase in the quality of the reports on local events. ${ }^{91}$

\section{Conclusion}

The introduction of the motor vehicle, much as the introduction of the horse had done one hundred years before, led to major changes within central Namibian societies. Motor vehicles became an indispensable attribute of South African colonial rule in Namibia and came to be deployed in all manner of situations, even when the utilitarian aspects of the new technology were negligible. Perhaps most important, the introduction of the motorcar to Namibia led to the development of new hierarchies of power and status based upon access to cars. ${ }^{92}$ Colonial administrators and Herero leaders used motorcars to

89 VEMA RMG 2514 b, Kuhlmann in Omaruru, 30/9/21, Halbjahrsbericht vom 1 April bis 30 September, describes a five-week ox-wagon trip.

90 VEMA RMG 2503 a, Pardey in Grootfontein, 2/4/30, Bericht vom 1/10/29-31/3/30. JBG's translation.

91 VEMA RMG 1703, Werner in Windhoek [?], 21/12/33, to Olpp; and RMG 2501 a, Tschäschke in Gobabis, Halbjahrsbericht $1 / 1 / 33-30 / 6 / 33$, describes a car breakdown in the reserve.

92 With thanks to Dag Henrichsen, who drew my attention to the "new hierarchies" and the parallels with nineteenth-century developments. 
emphasize their status. In a process that mirrored that of the German settler community, Herero Otruppe used cars and trucks to add power to their spectacular parades. In short, the car and truck came to be used to increase the stature and standing of all those associated with them. The motorcar dramatically changed the way in which people came to see distance and physical landscapes and also the manner in which people came to relate to one another. The motorcar brought greater mobility and consequently contact among people, yet at the same time it led to the loss of contact and understanding between the missionaries and large sections of central Namibia's population. Henceforth missionaries came to view the societies to which they sought to preach in terms of accessibility by car. In addition, cut off from large mediating groups of traveling companions, the missionaries could and did tend to burst in upon communities without much preparation. Consequently contact with and insight into Herero society suffered tremendously. 